\title{
PENGEMBANGAN MEDIA BLOG SEJARAH UNTUK PEMBELAJARAN SEJARAH DI SMA
}

\author{
M. Nur Rokhman, M. Pd, Sardiman AM, M. Pd, dan \\ Rendra Pramandanu \\ (Pendidikan Sejarah, FIS, Universitas Negeri Yogyakarta) \\ Email: nurokhman@uny.ac.id; sardiman@uny.ac.id
}

\begin{abstract}
ABSTRAK
Penelitian ini bertujuan untuk: (1) mengembangkan Media dan Bahan ajar Blog Sejarah pada materi masuknya Hindu Buddha di Indonesia untuk pembelajaran SMA dan (2) mengetahui kelayakan Blog sejarah tersebut berdasarkan penilaian ahli materi, ahli media, guru dan siswa. Penelitian ini adalah penelitian pengembangan (Research and Development) melalui 10 langkah pengembangan, yaitu: (1) potensi masalah, (2) mengumpulkan informasi/ data, (3) design produk, (4) validasi design, (5) perbaikan design, (6) ujicoba produk, (7) revisi produk, (8) uji coba pemakaian, (9) revisi produk, dan (10) pembuatan produk. Tehnik pengumpulan data menggunakan lembar penilaian. Analisis data menggunakan analisis deskriptif kuantitatif. Hasil penelitian ini adalah Blog sejarah materi Hindu Buddha untuk peserta didik SMA/MA kelas XI. Berdasarkan penilaian ahli materi produk akhir Blog sejarah ini memperoleh skor rerata $81,2 \%$, penilaian dari ahli media produk ahir Blog sejarah memperoleh skor rerata $80,8 \%$ kemudian produk tahap ahir dari guru memperoleh $84,4 \%$ dan dari siswa $82,9 \%$. Keseluruan rata rata adalah $82,2 \%$ dengan kategori sangat baik.
\end{abstract}

\section{Kata kunci : Media Blog, Blog sejarah, Hindu Buddha}

\begin{abstract}
This study aims to: (1) develop teaching materials Blog Media and History at the entry of Hindu Buddhist materials in Indonesia for teaching senior high school and (2) determine feasibility this history Blog based assessment materials experts, media experts, teachers and students. This research is the development research (Research and Development) through the 10 steps of development, there are: (1) the potential problem, (2) gathering information / data, (3) the design of products, (4) validation of design, (5) improvement of design, (6) test products, (7) product revision, (8) utility testing, (9) the revision of the product, and (10) the manufacture of products. Data collection techniques using the assessment sheet. Data analysis using quantitative descriptive analysis. Results of this research is the material history of Hindu Buddhist Blog for senior high school students / MA class XI. Based on the expert assessment of the final product material Blog this history gained an average score of $81.2 \%$, a media expert assessment of the final Blog historical products obtain mean score of $80.8 \%$ and the product of the last stage of teachers acquire $84.4 \%$ and $82.9 \%$ of students, all of average is $82.2 \%$ with a very good category.
\end{abstract}

Keywords: Blog media, history blog, Hindu Buddha 


\section{Pendahuluan}

Di dalam dunia pendidikan kita mengenal berbagai macam media pembelajaran. Media tersebut dapat berupa penggunaan alat peraga ataupun bukan alat. Banyak media pembelajaran dalam bentuk alat peraga yang masih kurang menarik minat siswa dan juga teramat rumit untuk dipelajari guru, dikarenakan kurang atraktif dan monoton serta susah dalam penguasaan media tersebut. Salah satu media pembelajaran yang sekarang ini dapat dikembangkan adalah dengan memanfaatkan teknologi komputer sebagai media pembelajaran. Hal ini didukung dengan perkembangan teknologi dan juga komunikasi. Hal ini dipermudah pula dengan adanya jaringan internet yang dapat membuka jendela dunia dalam 1 kali klik. Perkembangan teknologi komputer terutama dalam bidang perangkat lunak yang kini kian lama makin pesat dan sangat mendukung dalam pengembangan media pembelajaran dan juga mempermudah guru untuk menyampaikan materi dalam bentuk media pembelajaran.

Dalam upaya meningkatkan mutu pembelajaran sejarah, media pembelajaran sejarah sangat dibutuhkan. Kehadiran teknologi komputer dan kemajuan internet sangat mendukung dalam pengembangan media pembelajaran. Pembelajaran dengan media komputer akan sangat membantu siswa dalam memahami materi pembelajaran sejarah, karena dengan komputer memungkinkan untuk menghadirkan bentuk pembelajaran yang menarik, efektif dan efisien. Dengan komputer dapat disajikan media pembelajaran yang memuat materi pembelajaran tekstual dan visual. Dengan hadirnya internet semua peserta didik dapat mengakses pembelajaran sejarah dimanapun mereka berada. Salah satu perangkat lunak dengan computer yang dapat membantu dalam pengembangan media pembelajaran sejarah adalah Media Blog. Blog merupakan sebuah aplikasi CMS (Content Management System) yaitu perangkat lunak yang memungkinkan seseorang untuk menambahkan dan atau memanipulasi (mengubah) isi dari suatu situs Web. Umumnya, sebuah CMS (Content Management System) terdiri dari dua elemen: aplikasi manajemen isi (Content Management Application, [CMA]); aplikasi pengiriman isi (Content Delivery Application [CDA]).

Elemen CMA memperbolehkan pembuat untuk memanajer isi yang mungkin tidak memiliki pengetahuan mengenai HTML (HyperText Markup Language), untuk memenejemen pembuatan, modifikasi, dan penghapusan isi dari suatu situs Web tanpa perlu memiliki keahlian sebagai seorang Webmaster. Elemen CDA menggunakan dan menghimpun informasiinformasi yang sebelumnya telah ditambah, dikurangi atau diubah oleh pembuat situs web untuk meng-update atau memperbaharui situs Web tersebut. Kemampuan atau fitur dari sebuah sistem CMS berbeda-beda, walaupun begitu, kebanyakan dari software ini memiliki fitur publikasi berbasis Web, manajemen format, kontrol revisi, pembuatan index, pencarian, dan pengarsipan.

Dengan media blog ini mudah untuk memberikan materi pembelajaran pasca penerimaan pelajaran di sekolah ataupun sebelum pelajaran sekolah dilaksanakan. Dengan beberapa aspek tersebut maka media Blog sangat dibutuhkan untuk menutupi dan melengkapi waktu mengajar yang sangat kurang di sekolah. Dengan mengantisipasi

M. Nur Rokhman, dkk, Pengembangan Media Blog Sejarah untuk Pembelajaran Sejarah di SMA 
masalah seperti ini juga media pembelajaran Blog adalah solusi untuk mengatasi kurangnya waktu pembelajaran di sekolah. Media pembelajaran Blog ini juga bisa diakses di rumah dengan mudah, sepanjang ada jaringan internet. Belajar menurut Moh. Surya (1981:32), adalah suatu proses usaha yang dilakukan individu untuk memperoleh suatu perubahan tingkah laku yang baru keseluruhan, sebagai hasil pengalaman individu itu sendiri dalam interaksinya dengan lingkungan. Kesimpulan yang bisa diambil dari kedua pengertian di atas, bahwa pada prinsipnya, belajar adalah perubahan dari diri seseorang. Belajar merupakan suatu proses perubahan tingkah laku sebagai hasil interaksi individu dengan lingkungannya dalam memenuhi kebutuhan hidupnya. Menurut Reber yang dikutip oleh Sugihartono, dkk belajar diartikan dalam 2 pengertian. Pertama, belajar sebagai proses memperoleh pengetahuan dan kedua, belajar sebagai perubahan kemampuan bereaksi yang relative langgeng sebagai hasil latihan yang diperkuat sumber dari Sugihartono (2007:74) menyimpulkan bahwa belajar merupakan suatu proses memperoleh pengetahuan dan pengalaman dalam wujud perubahan tingkah laku dan kemampuan bereaksi yang relative permanen atau menetap karena adanya interaksi individu dengan lingkungannya.

Dari berbagai pendapat tersebut dapat disimpulakan bahwa belajar adalah sebuah proses dimana dari yang tidak tahu untuk menjadi tahu dari yang tidak paham bisa menjadi paham. Bisa disebut juga berpetualangan namun berpetualangan dengan ilmu pengetahuan ataupuan non ilmu pengetahuan didapat dalam pendidikan formal ataupun non formal. Undang-Undang RI No 20 Tahun 2003 tentang Sistem Pendidikan Nasional Bab 1 Pasal 1 (1) pendidikan didefinisikan sebagai usaha sadar dan terencana untuk mewujudkan suasana belajar dan proses belajar agar peserta didik secara aktif mengembangkan potensi dirinya untuk memiliki kekuatan spiritual keagamaan, pengendalian diri, kepribadian, kecerdasan, akhlak mulia, serta keterampilan yang diperlukan dirinya, masyarakat, bangsa dan negara. Dalam pembelajaran tentu ada suatu cara atau teknik tertentu, baik itu penyampaian maupun media yang digunakan.Salah satu metode yang banyak berkembang adalah pembelajaran melalui media visualisasi dalam bentuk penyajian butir-butir kalimat yang dilengkapi dengan gambar-gambar dan suara.

Pembelajaran adalah membelajarkan siswa menggunakan asas pendidikan maupun teori belajar yang merupakan penentu utama keberhasilan pendidikan. Pembelajaran merupakan komunikasi dua arah, mengajar dilakukan pihak guru sebagai pendidik, sedangkan belajar dilakukan oleh peserta didik atau murid. Menurut Mulyasa (2005: 110) pembelajaran pada hakikatnya adalah proses interaksi antara peserta didik dan lingkungannya, sehingga terjadi perubahan perilaku kearah yang lebih baik, dimana dalam interaksi tersebut banyak sekali faktor yang mempengaruhinya, baik faktor internal yang berasal dari dala individu, maupun faktor eksternal yang datang dari lingkungan.

Berdasarkan definisi tersebut dapat disimpulkan bahwa pembelajaran adalah kegiatan yang dilaksanakan oleh guru dan siswa berupa aktivitas belajar mengajar. Dalam proses pembelajaran dilaksanakan dengan memanfaatkan metode. Pembelajaran sejarah memiliki arti strategis dalam pembentukan watak dan peradaban bangsa yang bermartabat serta dalam pembentukan manusia Indonesia yang

M. Nur Rokhman, dkk, Pengembangan Media Blog Sejarah untuk Pembelajaran Sejarah di SMA 


\section{Volume 10 No 2 Maret 2015}

memiliki rasa kebangsaan dan cinta tanah air. Hal ini karena pengetahuan masa lampau tersebut mengandung nilai-nilai kearifan yang dapat digunakan untuk melatih kecerdasan, membentuk sikap, watak, dan kepribadian peserta didik (Lampiran Permendiknas No. 22 tahun 2006). Dalam melaksanakan kegiatan belajar mengajar tentunya banyak faktor yang mempengaruhi berhasil atau tidaknya kegiatan belajar mengajar. Faktor yang mempengaruhi belajar dibedakan menjadi dua golongan, yaitu faktor intern dan faktor ekstern. Faktor intern adalah faktor yang ada dalam diri individu yang sedang belajar, sedangkan faktor ekstern adalah faktor yang berada di luar individu (Slameto, 2003:54).

Faktor Intern antara lain: faktor faktor jasmaniah (faktor kesehatan dan cacat tubuh); faktor psikologis (intelligensi, perhatian, minat, bakat, motif, kematangan, dan kesiapan); dan faktor kelelahan (kelelahan jasmani dan rohani). Yang termasuk faktor ektern antara lain faktor keluarga (cara orang tua mendidik, relasi antar anggota keluarga, suasana rumah, keadaan ekonomi keluarga, pengertian orang tua, dan latar belakang kebudayaan); faktor sekolah (metode mengajar, kurikulum, relasi guru dan siswa, disiplin sekolah, alat pengajaran, standar pelajajaran di atas ukuran, keadaan gedung, metode mengajar, dan tugas rumah); dan faktor masyarakat (kegiatan siswa dalam masyarakat, mediamassa, teman bergaul, dan bentuk kehidupan masyarakat (Slameto, 2003:55).

Nana Syaodikh (2005:208) mengungkapkan bahwa e-learning memiliki beberapa kelebihan dibanding belajar di sekolah. Kelebihan tersebut diantaranya keleluasaan dan kebebasan tempat karena dapat diakses di mana saja dan kapan saja, namun $e$-learning tidak dapat menggantikan belajar di sekolah. Menurut Nana Syaodikh (2005:208) Belajar di sekolah memiliki beberapa keunggulan dibanding e-learning , yaitu:

- Proses pembelajaran hanya bisa terjadi dalam interaksi langsung, segi-segi afektif seperti sikap, nilai, apresiasi, kehalusan perasaan tidak bisa dinilai secara optimal

- Pengembangan kemampuan-kemampuan dasar tidak bisa dipelajari sendiri, tetapi membutuhkan bimbingan, latihan dan pendampingan guru secara langsung

- Pada pendidikan dasar untuk segi-segi nilai membutuhkan contoh langsung.

- Pengembangan nilai dan keterampilan sosial lebih efektif dilakukan melalui situasi langsung dalam interaksi dan kerja kelompok.

- Dalam belajar di sekolah terjadi experience atau pertukaran pengalaman dengan teman sekelas atau teman sekelompok, para peserta didik tidak hanya belajar dari guru tapi juga dari temannya.

Menurut Eli Rohaeti (2006:77), proses pembelajaran secara online dapat diselenggarakan dalam berbagai cara, antara lain:

- Proses pembelajaran secara konvensional (lebih banyak face to face meeting) dengan tambahan pembelajaran melalui media interaktif komputer via internet.

- Dengan metode campuran, yakni secara umum sebagian proses pembelajaran dilakukan melalui komputer, namun tetap memerlukan face to face meeting untuk kepentingan tutorial atau mendiskusikan bahan ajar.

- Metode pembelajaran yang secara keseluruhan hanya dilakukan secara online, pada metode ini sama sekali tidak menggunakan face to face meeting. 
Dari uraian tersebut di atas didapatkan perincian pentingnya pengembangan media pembelajaran sejarah berbentuk multimedia interaktif blog sejarah. Berangkat dari latar belakang itulah, maka penelitian dengan judul "Pengembangan media Blog Sejarah untuk pembelajaran Sejarah siswa SMA" perlu dilakukan.

\section{Metode Penelitian}

Penelitian ini merupakan penelitian pengembangan. Penelitian pengembangan adalah penelitian yang bertujuan untuk mengembangkan pengetahuan, teori pendidikan yang sudah ada atau menghasilkan suatu produk di bidang pendidikan (Sukardjo dan Lis Permana Sari, 2009:65). Penelitian dan pengembangan yang dalam bahasa Inggris sering dituliskan sebagai Research and Development $(R \& D)$ merupakan salah satu metode penelitian yang bertujuan untuk menghasilkan suatu produk baru dan menguji kelayakan dan kualitas produk tersebut. Dengan demikian orientasi penelitian pengembangan adalah produk (Sugiyono, 2011:297). Borg dan Gall menyatakan bahwa penelitian dan pengembangan $(R \& D)$ merupakan metode penelitian yang digunakan untuk mengembangkan atau memvalidasi produkproduk yang digunakan dalam pendidikan dan pembelajaran (Sugiyono, 2007:4). Produk-produk yang dihasilkan dalam penelitian pengembangan bidang pendidikan antara lain materi-materi pelatihan pendidik, materi belajar untuk siswa, media pembelajaran, sistem pembelajaran, metode pembelajaran, pendekatan, model pembelajaran, dan lain-lain.

Penelitian dan pengembangan merupakan jembatan antara penelitian dasar (basic research) dan penelitian terapan (applied research) (Sugiyono, 2007:4).
Penelitian pengembangan bersifat analisis kebutuhan dan dapat menguji keefektifan produk yang dihasilkan supaya dapat berfungsi di masyaraat luas, artinya untuk dapat menghasilkan produk tertentu yang siap pakai dan layak, maka diperlukan analisis kebutuhan masyarakat terlebih dulu. Teknik pengumpulan data merupakan langkah yang paling utama dalam suatu penelitian, karena tujuan utama dari penelitian adalah memperoleh data (Sugiyono, 2011:308). Agar data yang diperoleh dari proses pengumpulan data merupakan data yang valid, maka dalam penelitian ini harus menggunakan teknik pengumpulan data yang benar. Teknik atau cara yang digunakan dalam pengumpulan data adalah menggunakan lembar penilaian. Dengan tujuan agar menentukan kelayakan media pembelajaran Sejarah dengan Blog Sejarah. Lembar penilaian digunakan saat uji ahli, evaluasi guru pengampu, dan uji coba produk. Hasil penelitian kemudian dianalisis dan dideskripsikan.Instrumen penelitian merupakan alat yang digunakan untuk mengumpulkan data yang bermanfaat untuk menjawab permasalahan penelitian. Instrumen yang digunakan adalah lembar penilaian

Instrumen yang digunakan dalam penelitian ini ditujukan untuk menilai kelayakan media pembelajaran Sejarah di SMA, sebagai pendukung pada proses pembelajaran Sejarah dengan sistem internet. Data yang diperoleh dari lembar penilaian ini adalah data kuantitatif. Bentuk lembar penilaian yang digunakan adalah skala bertingkat yaitu sebuah pertanyaan diikuti oleh kolom-kolom yang menunjukan tingkatan-tingkatan (Suharsimi Arikunto, 1993 : 125).

Pada penelitian penggunaan media pembelajaran interaktif untuk meningkatkan

M. Nur Rokhman, dkk, Pengembangan Media Blog Sejarah untuk Pembelajaran Sejarah di SMA 


\section{Volume 10 No 2 Maret 2015}

motivasi belajar sejarah dengan menggunakan Blog sejarah ini digunakan 3 instrumen untuk mengetahui kelayakan media pembelajaran yang dibuat. Instrumen tersebut yaitu (1) instrumen uji kelayakan untuk ahli media dan materi pembelajaran blog, (2) instrumen uji untuk guru pengampu, (3) instrumen uji pemakai terbatas untuk siswa. Teknik analisis data yang digunakan adalah teknik analisis deskriptif kuantitatif, yaitu menganalisis data kuantitatif yang diperoleh dari lembar penilaian ahli dan uji lapangan. Skala yang digunakan untuk menentukan layak atau tidaknya media pembelajaran adalah Rating Scale yang dikembangkan oleh Sugiyono (2011: 97). Dalam skala model rating scale, responden tidak akan menjawab pertanyaan kualitatif yang telah disediakan. Jumlah alternatif respon yang digunakan adalah 4 titik (poin), yaitu angka 4,3,2 dan 1. Untuk angka 4 adalah sangat baik, angka 3 adalah kategori baik, angka 2 kategori cukup baik, dan angka 1 adalah kategori kurang baik.

\section{Hasil Penelitian dan Pembahasan Desain Materi}

Hasil yang diperoleh dari desain materi berupa kumpulan materi sebagai bahan untuk membuat produk. Dalam desain materi ini ada beberapa tahapan yang dilakukan, antara lain :

Identifikasi Kebutuhan

Untuk memperoleh materi sebagai bahan membuat produk awal diperlukan beberapa sumber. Sumber tersebut adalah silabus dan materi dari buku- buku referensi serta materi yang biasa digunakan oleh guru mata pelajaran sejarah kelas XI IPA . Disamping materi dari silabus dan dari buku referensi, pengembang perlu mengidentifikasi kebutuhan guru dan siswa untuk lebih menunjang proses pembelajaran.
Kebutuhan tersebut yaitu bahwa dalam pembelajaran sejarah masih dominan menggunakan metode konvensional (ceramah) dan kurangnya sumber belajar siswa berupa media pembelajaran yang dikemas secara menarik dan tidak membuat siswa merasa bosan, disamping itu padatnya materi sejarah menjadikan kurangnya waktu untuk pembelajaran sejarah.

Identifikasi Tujuan

Tujuan dari pengembangan media pembelajaran sejarah pada materi semester 1 adalah sebagai media pembelajaran untuk mendukung dan mempermudah pengajar dalam penyampaian materi dan membantu siswa untuk memahami materi-materi yang bisa diakses kapanpun di rumah atau dimanapun. Dengan mudahnya materi diakses oleh siswa kapan dan dimanpun maka akan mengurangi waktu pembelajaran di kelas. Tujuan umum dari pembelajaran media ini adalah memahami materi masuknya Hindu Buddha di Indonesia.

Tujuan khusus dari media pembelajaran ini siswa diharapkan dapat: Menguraikan dan menjelaskan materi semester 1 dari masuknya Hindu Buddha. Setelah mengidentifikasi kebutuhan dan tujuan, langkah selanjutnya adalah merumuskan butir materi yang telah diperoleh. Rumusan butir materi tersebut Proses masuk dan berkembangnya Hindu Buddha di indonesia dengan sub bab : (1) Masuknya Hindu Buddha, dan (2) Kerajaan dan peninggalannya.

\section{Desain Tampilan Media}

Analisis

Hasil analisis tahap perancangan media pembelajaran ini dibagi dua dalam tahap, yaitu tahap analisis spesifikasi teknis dan tahap analisis kerja program. Tahap analisis spesifikasi teknis untuk mengetahui

M. Nur Rokhman, dkk, Pengembangan Media Blog Sejarah untuk Pembelajaran Sejarah di SMA 
persyaratan minimal sebuah PC (personal computer) untuk dapat mengakses Blog sejarah. Media ini dapat bekerja dalam sistem operasi windows 98, XP atau 7 (Seven) dengan prosessor minimal $200 \mathrm{Mhz}$ dan memori 64 MB. Perangkat lunak yang digunakan dalam pembuatan media pembelajaran ini meliputi : wordpress sebagai program utama, php sebagai bahasa pemrograman, $M y S Q L$ sebagai penghimpun data base kemudian XAMPP sebagai web server dan sebagai software untuk dapat membuka media ini adalah alat perambah seperti mozila, internet explor, opera, safari google crome dll. Perangkat keras untuk menjalankan media pembelajaran dengan mediablog sejarah adalah sebuah unit komputer yang dilengkapi Optical Drive untuk keperluan membaca dan burning media pembelajaran dalam format $\mathrm{CD}, \mathrm{LCD}$ untuk menampilkan program, keyboard dan mouse standar windows serta akses internet untuk keperluan interaksi dengan program.

Adapaun hasil identifikasi dari tahap analisis kerja program multimedia ini antara lain :

- Pada saat program dijalankan maka akan ditampilkan menu utama media pembelajaran dengan tombol-tombol menarik yang terdiri dari home, materi, latihan soal, video,foto profil, fitur chat on, webcame.

- Ketika tombol home di-klikmaka muncul halaman utama pada media blog sejarah.

- Ketika tombol beberapa judul materi diklik maka muncul halaman utama materi sesuai judul yang di-klik.

- Dalam halaman materi yang disajikan ada 5 materi yang terdapat dalam slide dan beberapa materi ada dalam barisan judul.

- Ketika di-klik pada ujian maka muncul halaman latihan soal yang pada awalnya diminta untuk mengisi nama, dan terdapat
10 soal yang dikeluarkan satu persatu secara acak.

- Video diletakan pada materi sesuai isi video. Ketika video di klik akan muncul ilustrasi isi materi sejarah

\section{Desain Program}

Desain arsitektur

Desain arsitektur adalah tahap setelah analisis dan data yang akan ditampilkan telah dipersiapkan. Dengan membuat diagram alur program berupa bagan dengan simbol-simbol tertentu yang menggambarkan urutan proses secara mendetail dalam suatu program. Desain Interface, tampilan dan penjelasan. Tahap desain interface adalah penggambaran mengenai struktur program. Desain interface atau tampilan dibuat untuk memudahkan dalam menterjemahkan ke dalam bentuk bahasa pemrograman. Desain interface dibuat berdasarkan flowchart yang telah dibuat pada tahap desain arsitektur. Petunjuk pengoperasian media pembelajaran sejarah dengan blog sejarah adalah sebagai berikut :

- Untuk membuka media ada buka mesin perambah terlebih dahulu, kemudian isi alamat perambahan dengan dengan mengetik (sejarah.mongosilakan.net), maka akan muncul tampilan halaman menu utama.

- Dalam menu utama terdapat halaman materi sesuai judul yang dikehendaki, apabila diklik akan pergi ke materi yang dikehendaki, dan dalam setiap ahir materi terdapat video penjelasan

- Ketika di-klik ujian materi maka akan muncul pengisian nama, setelah itu isilah nama, kemudian klik tombol mulai, maka akan muncul soal latihan pilihan ganda yang setiap siswa tinggal memuilih pilian ganda, ketika siswa menjawab salah maka

M. Nur Rokhman, dkk, Pengembangan Media Blog Sejarah untuk Pembelajaran Sejarah di SMA 


\section{Volume 10 No 2 Maret 2015}

akan keluar pemberitahuan tanda salah begitu juga sebaliknya.

- Ketika tombol "profil" di-klik maka akan muncul gambar foto pengembang serta biodata masing- masing.

- Apabila klik skype "call me" maka akan keluar web came yang berguna untuk mendekatkan yang jauh atau berhalangan hadir

- Apabila klik chat on maka anda diminta mengisi nama dan alamat email dan anda dapat bertanya langsung dengan pemilik web/pengajar

\section{Data Validasi Produk}

Dalam penelitian pengembangan ini diperoleh dua data validasi produk, yaitu data validasi ahli materi dan ahli media. Sebelum dilaksanakan uji coba lapangan, untuk mengetahui kelayakan produk media dari sisi materi dan media perlu mendapatkan validasi dari ahli materi dan ahli media. Evaluasi materi dilaksanakan oleh dosen Jurusan Pendidikan Sejarah Universitas Negeri Yogyakarta, sedangkan evaluasi ahli media dilaksanakan oleh dosen ahli media pembelajaran adalah seorang web master sarjana lulusan Universitas Negeri Yogyakarta.

Data Validasi Ahli Materi

Deskripsi Data Validasi Ahli Materi

Media pembelajaran materi

masuknya Hindu Buddha di Indonesia dengan Blog sejarah yang dikembangkan ini divalidasi oleh ahli materi Bapak M. Nur Rokhman, M.Pd. Beliau adalah dosen pengajar mata kuliah Sejarah Indonesia Abad XVI- XVIII di Fakultas Ilmu Sosial Jurusan Pendidikan Sejarah. Validasi ahli materi terdiri dari aspek isi materi dan aspek desain media pembelajaran sejarah dengan Blog sejarah. Masukan yang didapat dari ahli materi digunakan sebagai dasar acuan untuk merevisi produk media pembelajaran. Penilaian dari ahli materi dilakukan melalui beberapa tahap. Penilaian tahap 1 dapat dilihat pada tabel berikut. Hasil penilaian ahli materi ditinjau dari aspek pembelajaran dan materi diperoleh (1) kejelasan standar kompetensi memperoleh penilaian cukup baik, (2) kejelasan kompetensi dasar memperoleh penilaian cukup baik, (3) kemampuan penyampaian materi memperoleh penilaian cukup baik, (4) kejelasan isi media memperoleh penilaian cukup baik, (5) ketepatan materi memperoleh penilaian cukup baik, (6) pentingnya materi memperoleh penilaian baik, (7) manfaat materi memperoleh penilaian baik, (8) daya tarik materi memperoleh penilaian baik, (9) kebenaran konsep memperoleh penilaian cukup baik, (10) kebenaran materi memperoleh penilaian baik, (11) kesesuaian dengan kurikulum memperoleh penilaian cukup baik, dan (12) kesesuaian materi dengan situasi siswa memperoleh penilaian baik. Hasil validasi ahli materi pada pengembangan media pembelajaran sejarah dengan blog sejarah dapat disimpulkan bahwa kedua aspek setelah dijumlah tergolong dalam kategori baik, lebih jelasnya dapat dilihat pada gambar dibawah

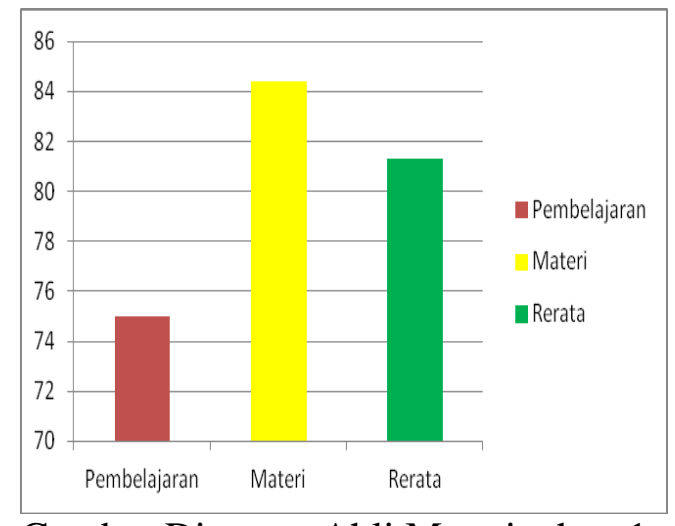

Gambar Diagram Ahli Materi tahap 1

M. Nur Rokhman, dkk, Pengembangan Media Blog Sejarah untuk Pembelajaran Sejarah di SMA 


\section{Volume 10 No 2 Maret 2015}

Adapun catatan dari ahli materi adalah sebagai berikut :

- Materinya lebih dilengkapi karena materi terlalu dangkal untuk anak SMA.

- Tatanan materi lebih diurutkan agar mudah mencarinya.

Setelah diadakan perbaikan hasil validasi tahap ke 2 dapat disajian sebagai berikut : Dari data yang diperoleh diketahui bahwa jumlah skor penilaian adalah 31 dengan rerata 2,6 Setelah dikonversikan pada persentase didapat hasil 64,6.

Dari hasil penilaian ahli materi ditinjau dari aspek pembelajaran dan materi diperoleh (1) kejelasan standar kompetensi memperoleh penilaian baik, (2) kejelasan kompetensi dasar memperoleh penilaian baik, (3) kemampuan penyampaian materi memperoleh penilaian baik, (4) kejelasan isi media memperoleh penilaian cukup baik, (5) ketepatan materi memperoleh penilaian cukup baik, (6) pentingnya materi memperoleh penilaian baik, (7) manfaat materi memperoleh penilaian baik, (8) daya tarik materi memperoleh penilaian baik, (9) kebenaran konsep memperoleh penilaian cukup baik, (10) kebenaran materi memperoleh penilaian baik, (11) kesesuaian dengan kurikulum memperoleh penilaian cukup baik, dan (12) kesesuaian materi dengan situasi siswa memperoleh penilaian baik. Hasil validasi ahli materi pada pengembangan media pembelajaran sejarah dengan blog sejarah dapat disimpulkan bahwa kedua aspek setelah dijumlah tergolong dalam kategori baik, lebih jelasnya dapat dilihat pada gambar dibawah

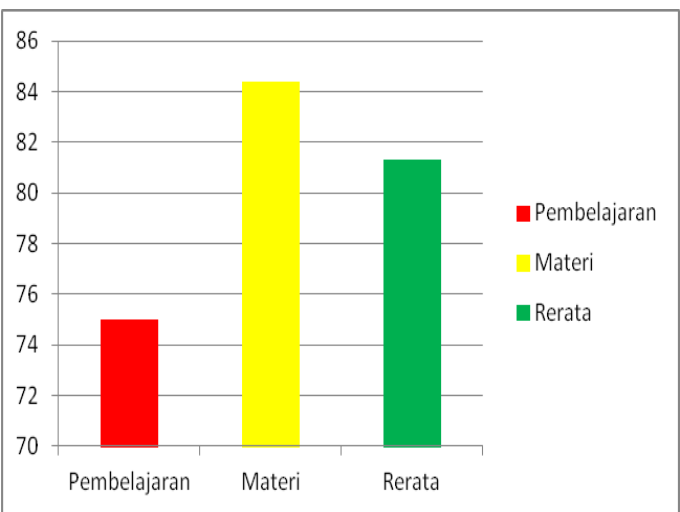

Gambar Diagram Ahli Materi tahap 2

Dengan demikian skor materi telah mengalalami kenaikan sebesar 4,2.

Dari data yang diperoleh diketahui bahwa jumlah skor penilaian adalah 39 dengan rerata3,25 Setelah dikonversikan pada persentase didapat hasil 81.3, dengan kategori sangat baik. Dari hasil penilaian ahli materi ditinjau dari aspek pembelajaran dan materi diperoleh (1) kejelasan standar kompetensi memperoleh penilaian baik, (2) kejelasan kompetensi dasar memperoleh penilaian baik, (3) kemampuan penyampaian materi memperoleh penilaian baik, (4) kejelasan isi media memperoleh penilaian baik, (5) ketepatan materi memperoleh penilaian sangat baik, (6) pentingnya materi memperoleh penilaian baik, (7) manfaat materi memperoleh penilaian baik, (8) daya tarik materi memperoleh penilaian baik, (9) kebenaran konsep memperoleh penilaian sangat baik, (10) kebenaran materi memperoleh penilaian baik, (11) kesesuaian dengan kurikulum memperoleh penilaian sangat baik, dan (12) kesesuaian materi dengan situasi siswa memperoleh penilaian baik. Hasil validasi ahli materi pada pengembangan media pembelajaran sejarah dengan blog sejarah dapat disimpulkan bahwa kedua aspek setelah dijumlah tergolong dalam kategori 
sangat baik, lebih jelasnya dapat dilihat pada gambar dibawah

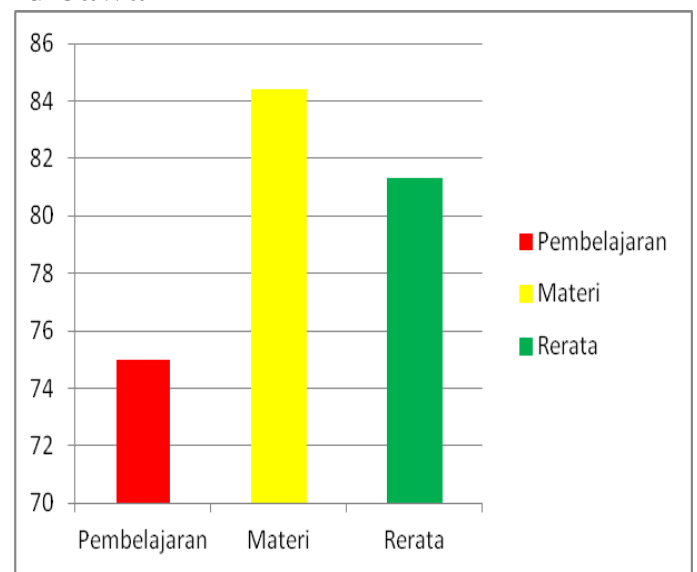

Gambar Diagram Ahli Materi tahap 3

Hasil validasi tahap 3 sudah baik dan sudah dapat digunakan untuk dilengkapkan pada blog.

\section{Data Validasi Ahli Media}

Validasi ahli media dilakukan oleh saudara Bowo soetedja .Spd beliau adalah lulusan UNY tehnik informatika dan web master salah satu game dunia. Validasi ahli media ini bertujuan untuk mengetahui aspek komunikasi, desain, dan format sajian serta kelayakan baik dari sisi media. Masukan yang didapat dari ahli media digunakansebagai dasar acuan untuk merevisi produk media pembelajaran penilaian tahap 1 dapat dilihat pada tabel berikut : Dari data yang diperoleh diketahui bahwa jumlah skor penilaian adalah 36 dengan rerata 2,8 Setelah dikonversikan pada persentase didapat hasil $69,2 \%$ dengan kategori sangat baik.

Dari hasil penilaian ahli media ditinjau dari aspek komunikasi, desain dan format sajian diperoleh (1) logika berpikir memperoleh penilaian baik, (2) interaksi pengguna dengan media memperoleh penilaian baik, (3) penggunaan bahasa memperoleh penilaian cukup baik, (4) keterbacaan teks memperoleh penilaian baik, (5) tampilan layar memperoleh penilaian baik, (6) grafis background memperoleh penilaian baik, (7) ukuran teks memperoleh penilaian baik, (8) ilustrasi dan warna memperoleh penilaian baik, (9) gambar pendukung memperoleh penilaian cukup, (10) kemudahan pengguna memperoleh penilaian baik, (11) urutan penyajian memperoleh penilaian baik, (12) kejelasan uraian materi memperoleh penilaian cukupt baik, (13) navigasi mudah memperoleh penilaian baik. Hasil validasi ahli media pada pengembangan media pembelajaran sejarah dengan blog sejarah dapat disimpulkan bahwa ketiga aspek setelah dijumlah tergolong dalam kategori baik, lebih jelasnya dapat dilihat pada gambar dibawah ini.

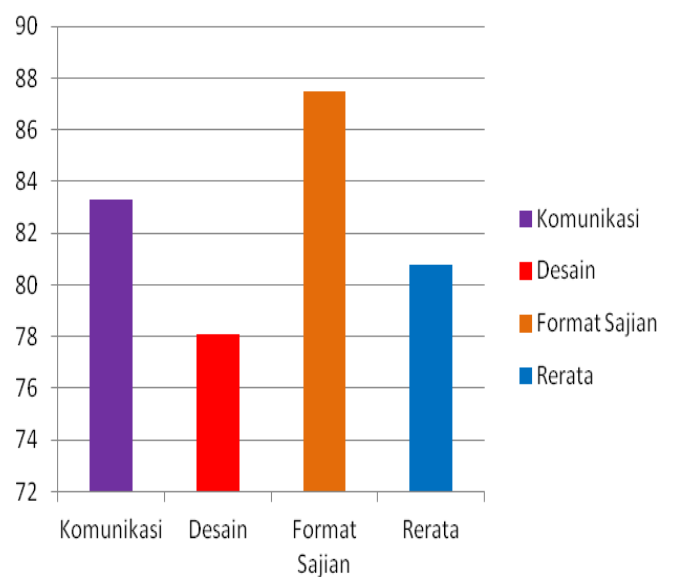

Gambar Diagram Ahli Media

Tahap 2 dari data yang diperoleh diketahui bahwa jumlah skor penilaian adalah 40 dengan rerata 3,08. Setelah dikonversikan pada persentase didapat hasil 76, 92\% dengan kategori sangat baik. Dari hasil penilaian ahli media ditinjau dari aspek komunikasi, desain dan format sajian diperoleh (1) logika berpikir memperoleh penilaian baik, (2) interaksi pengguna 


\section{Volume 10 No 2 Maret 2015}

dengan media memperoleh penilaian baik, (3) penggunaan bahasa memperoleh penilaian sangat baik, (4) keterbacaan teks memperoleh penilaian baik, (5) tampilan layar memperoleh penilaian baik, (6) grafis background memperoleh penilaian baik, (7) ukuran teks memperoleh penilaian baik, (8) ilustrasi dan warna memperoleh penilaian baik, (9) gambar pendukung memperoleh penilaian cukup, (10) kemudahan pengguna memperoleh penilaian baik, (11) urutan penyajian memperoleh penilaian baik, (12) kejelasan uraian materi memperoleh penilaian sangat baik, (13) navigasi mudah memperoleh penilaian baik. Hasil validasi ahli media pada pengembangan media pembelajaran sejarah dengan blog sejarahdapat disimpulkan bahwa ketiga aspek setelah dijumlah tergolong dalam kategori sangat baik, lebih jelasnya dapat dilihat pada gambar dibawah ini.

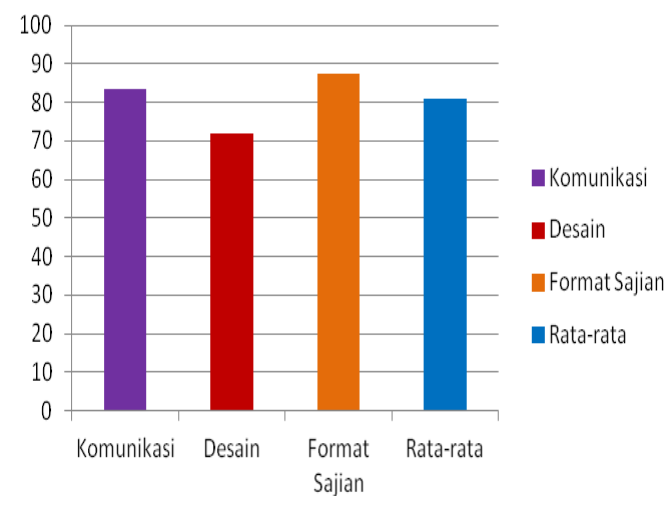

Gambar Diagram Ahli Media

Dengan demikian skor maedia telah mengalalami kenaikan sebesar 7,72

Setelah diadakan perbaikan hasil validasi tahap ke 3 sebagai berikut: Dari data yang diperoleh diketahui bahwa jumlah skor penilaian adalah 42 dengan rerata 3,2. Setelah dikonversikan pada persentase didapat hasil 80,8\% dengan kategori sangat baik. Dari hasil penilaian ahli media ditinjau dari aspek komunikasi, desain dan format sajian diperoleh (1) logika berpikir memperoleh penilaian baik, (2) interaksi pengguna dengan media memperoleh penilaian baik, (3) penggunaan bahasa memperoleh penilaian sangat baik, (4) keterbacaan teks memperoleh penilaian baik, (5) tampilan layar memperoleh penilaian baik, (6) grafis background memperoleh penilaian baik, (7) ukuran teks memperoleh penilaian baik, (8) ilustrasi dan warna memperoleh penilaian baik, (9) gambar pendukung memperoleh penilaian sangat baik, (10) kemudahan pengguna memperoleh penilaian baik, (11) urutan penyajian memperoleh penilaian baik, (12) kejelasan uraian materi memperoleh penilaian sangat baik, (13) navigasi mudah memperoleh penilaian baik. Hasil validasi ahli media pada pengembangan media pembelajaran sejarah dengan blog sejarah dapat disimpulkan bahwa ketiga aspek setelah dijumlah tergolong dalam kategori sangat baik, lebih jelasnya dapat dilihat pada gambar dibawah ini.

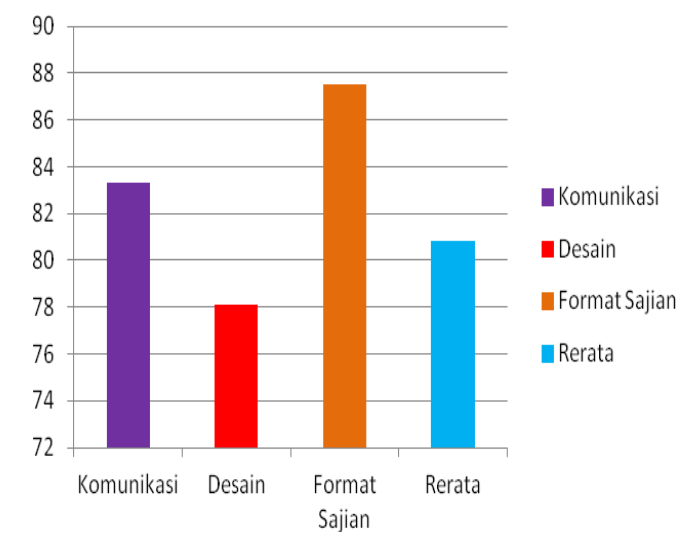

Gambar Diagram Ahli Media

Hasil validasi tahap 3 sudah baik dan sudah dapat digunakan untuk sebagai blog pembelajaran.

Data Evaluasi Guru Pengampu 
Penilaian ini dilakukan bersamaan uji coba produk di lapangan. Penilaian ini diberikan kepada guru pengampu mata pelajaran sejarah kelas XI IPA. Butir pertanyaan ini berjumlah 24 butir.

Deskripsi Data

Pengambilan data ini dilakukan setalah media di validasi oleh ahli materi dan ahli media pembelajaran kemudian direvisi dan baru di nilai oleh guru pengampu sejarah kelas XI IPA yakni Dra. Siti Aptinah Pertanyaan ini di bagi menjadi dua aspek yakni aspek materi dan aspek media. Dan data hasil evaluasi guru pengampu adalah sebagai berikut : Dari data yang diperoleh diketahui bahwa jumlah skor penilaian adalah 77 dengan rerata 3,2. Setelah dikonversikan pada persentase didapat hasil 80,2\% dengan kategori sangat baik.

Dari hasil evaluasi guru pengampu ditinjau dari aspek materi dan media diperoleh : (1) kejelasan standar kompetensi memperoleh kurang baik, (2) kejelasan kompetensi dasar memperoleh penilaian kurang baik, (3) kemampuan penyampaian materi memperoleh penilaian baik, (4) kejelasan isi media sangat baik, (5) ketepatan materi memperoleh penilaian baik, (6) Pentingnya materi memperoleh penilaian sangat baik, (7) manfaat materi memperoleh penilaian baik, (8) daya tarik materi memperoleh penilaian baik, (9) kesesuaian materi dengan situasi siswa memperoleh penilaian baik, (10) logika berpikir memperoleh penilaian baik, (11) interaksi pengguna dengan media memperoleh penilaian sangat baik, (12) penggunaan bahasa memperoleh penilaian baik, (13) keterbacaan teks memperoleh penilaian baik, (14) tampilan layar memperoleh penilaian sangat baik, (15) grafis background memperoleh penilaian baik, (16) ukuran teks memperoleh penilaian baik, (17) ilustrasi dan warna memperoleh penilaian sangat baik, (18) gambar pendukung memperoleh penilaian baik, (19) sajian animasi memperoleh penilaian baik, (20) daya dukung musik memperoleh penilaian baik, (21) urutan penyajian memperoleh sangat baik, (22) kejelasan uraian materi memperoleh penilaian sangat baik, (23) kemudahan pengguna memperoleh penilaian sangat baik, (24) antusias siswa memperoleh nilai sangat baik. Hasil evaluasi guru pengampu pada pengembangan media pembeljaran sejarah dengan blog dapat disimpulkan bahwa kedua aspek setelah dijumlah tergolong dalam kategori "sangat baik".

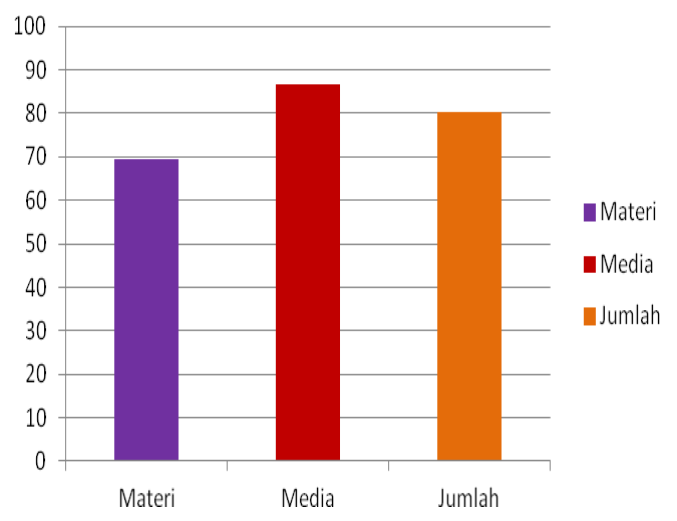

Gambar. Diagram Hasil Evaluasi Guru Pengampu tahap 1

Secara umum komentar dan saran penilaian guru pengampu dapat disimpulkan sebagai berikut :

Tahap 1

- Standar kopetensi belum ada

- Kembangkan pada materi sejarah yang lain.

- Sangat cocok untuk sumber belajar untuk siswa.

- Tingkatkan kualitas materi.

Setelah diadakan perbaikan hasil validasi tahap ke 2 dapat disajian sebagai berikut : Dari data yang diperoleh diketahui 
bahwa jumlah skor penilaian adalah 81 dengan rerata 3,4. Setelah dikonversikan pada persentase didapat hasil $84,4 \%$ dengan kategori sangat baik. Dari hasil evaluasi guru pengampu ditinjau dari aspek materi dan media diperoleh : (1) kejelasan standar kompetensi memperoleh baik, (2) kejelasan kompetensi dasar memperoleh penilaian baik, (3) kemampuan penyampaian materi memperoleh penilaian baik, (4) kejelasan isi media sangat baik, (5) ketepatan materi memperoleh penilaian baik, (6) Pentingnya materi memperoleh penilaian sangat baik, (7) manfaat materi memperoleh penilaian baik, (8) daya tarik materi memperoleh penilaian baik, (9) kesesuaian materi dengan situasi siswa memperoleh penilaian baik, (10) logika berpikir memperoleh penilaian baik, (11) interaksi pengguna dengan media memperoleh penilaian sangat baik, (12) penggunaan bahasa memperoleh penilaian baik, (13) keterbacaan teks memperoleh penilaian baik, (14) tampilan layar memperoleh penilaian sangat baik, (15) grafis background memperoleh penilaian baik, (16) ukuran teks memperoleh penilaian baik, (17) ilustrasi dan warna memperoleh penilaian sangat baik, (18) gambar pendukung memperoleh penilaian baik, (19) sajian animasi memperoleh penilaian baik, (20) daya dukung musik memperoleh penilaian baik, (21) urutan penyajian memperoleh sangat baik, (22) kejelasan uraian materi memperoleh penilaian sangat baik, (23) kemudahan pengguna memperoleh penilaian sangat baik, (24) antusias siswa memperoleh nilai sangat baik. Hasil evaluasi guru pengampu pada pengembangan media pembeljaran sejarah dengan blog dapat disimpulkan bahwa kedua aspek setelah dijumlah tergolong dalam kategori "sangat baik".

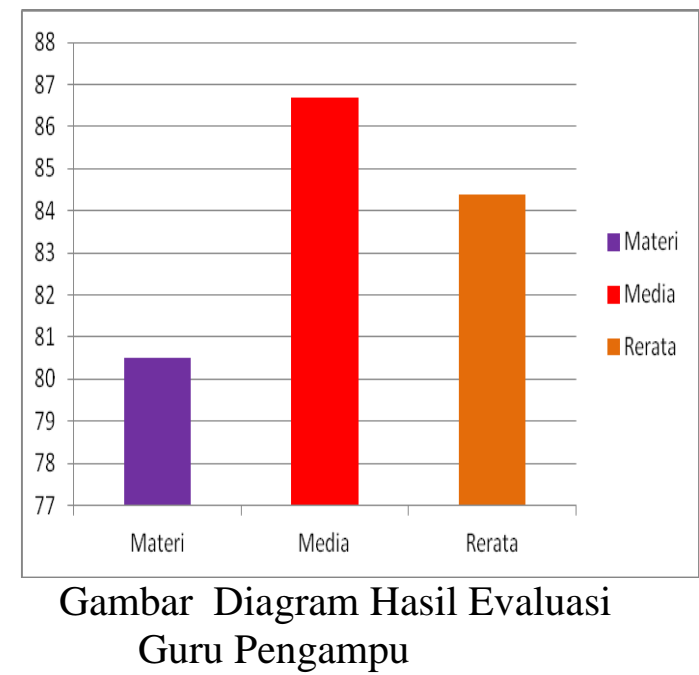

Hasil validasi tahap 2 sudah baik dan sudah dapat digunakan sebagai blog pembelajaran.

\section{Data Uji Coba Produk}

Data evaluasi ini berupa data uji coba produk di lapangan. Uji coba dilakukan di SMA 2 NGAGLIK, Sleman pada kelas XI IPA yang berjumlah 32 siswa. Dalam uji coba ini menggunakan butir pertanyaan yang berjumlah 11 butir pertanyaan.

Deskripsi data

Pengambilan data ini dilakukan setelah media di revisi dari validasi ahli materi dan ahli media dan di ujikan pada kelas XI IPA SMA 2 NGAGLIK, Sleman yang berjumlah 32 siswa Per kelas sebagai responden pada tanggal 25 april 2014. Aspek yang dinilai adalah materi, strategi pembelajaran, dan kualitas teknis. Data penilaian pada uji pemakai untuk siswa ini menggunakan angket. Dari data 32 siswa sebagai responden yang diperoleh pada uji coba produk diketahui bahwa jumlah skor penilaian adalah 1168 dengan rerata 3,31. Setelah dikonversikan pada persentase didapat hasil $82,9 \%$ dengan kategori sangat baik. 


\section{Komentar dan Saran Uji Coba Produk}

Secara umum komentar dan saran dalam uji coba produk dapat disimpulkan sebagai berikut :

- Sudah cukup bagus sebagai media pembelajaran yang menarik dan lebih dikembangkan.

- Supaya siswa dapat lebih paham ada baiknya materi dikembangkan lebih lengkap.

- Bisa dikembangkan pada materi bab lain. Analisis Data Pada Uji Coba Produk

Hasil uji coba lapangan yang diperoleh data uji coba produk dari aspek materi, startegi pembelajaran dan kualitas teknis. Tabel statistik menunjukan bahwa hasil penilaian uji coba produk mendapatkan nilai 82,9 \% dengan kategori sangat baik, jika digambarkan dalam bentuk diagram akan terlihat seperti berikut.

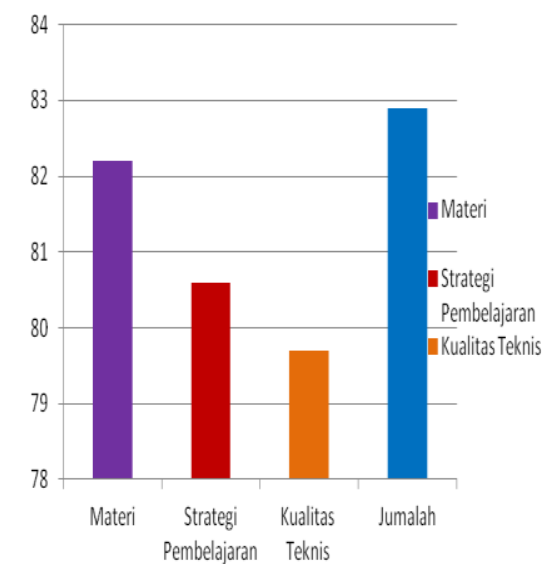

Gambar Diagram Hasil Uji Coba Produk

Dengan melihat gambar diatas, maka dapat diuraikan bahwa dari aspek materi media dengan blog sejarah memperoleh persentase sebesar 82,2 \%. Dari aspek strategi pembelajaran memperoleh persentase $80,6 \%$. Sedangkan dari aspek kualitas teknis memperoleh persentase sebesar 79,7 \%. Sehingga bila diambil rata- rata persentase dari penilaian uji coba produk, maka diperoleh persentase $82,9 \%$. Berdasarkan skala persentase pencapaian, maka media pembelajaran sejarah dengan blog sejarah, termasuk dalam kategori sangat baik. Sehingga media ini layak digunakan sebagai media pembelajaran

Produk akhir

Setelah dilakukan analisis dan evaluasi data uji coba produk, media pembelajaran sejarah dengan blog sejarah pada materi masuknya Hindu Buddha di Indonesia yang telah dikembangkan diperbaiki lagi pada tampilan agar lebih menarik, serta penambahan gambar maupun materi agar siswa menjadi lebih jelas.

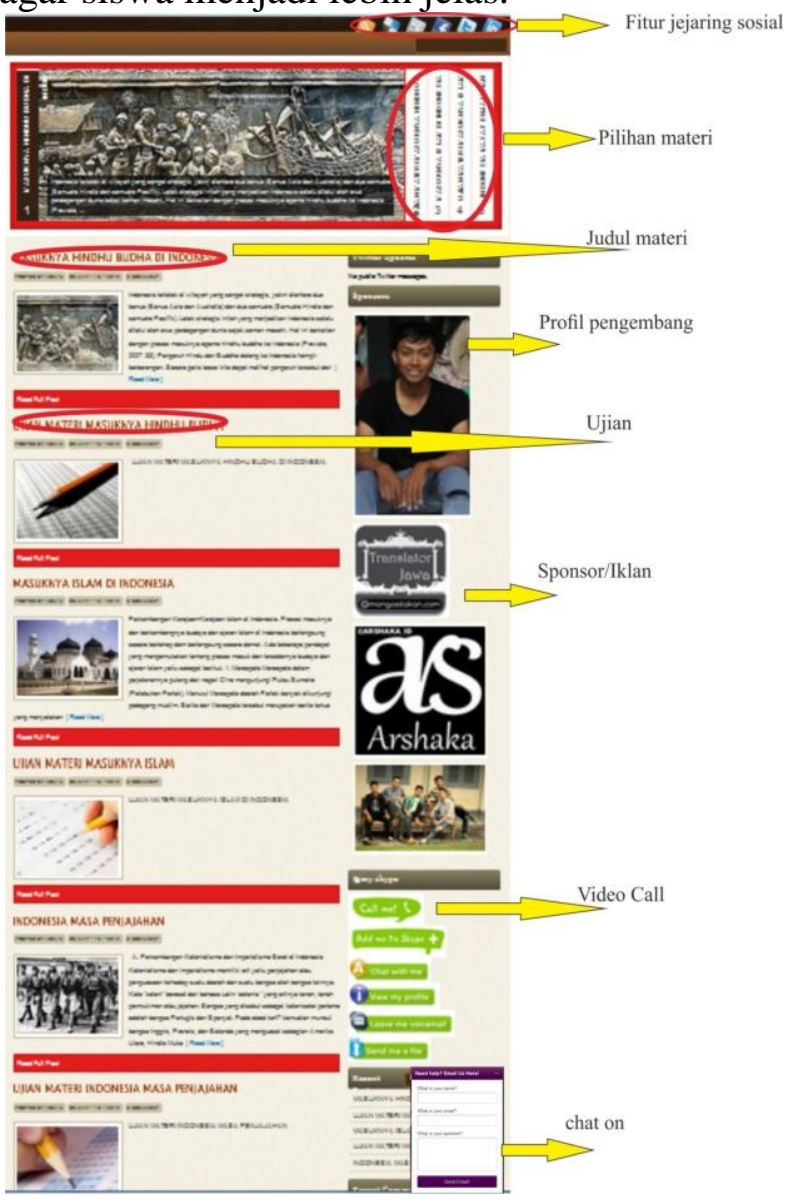




\section{Volume 10 No 2 Maret 2015}

\section{Hasil Penelitian dan Pembahasan}

Produk awal media blog sejarah ini pada awalnya masih terbilang sangat sederhana, hal ini terbukti dari beberapa revisi dari segi tampilan materi bahkan tata tempat pada blog. Revisi yang dilakukan baik oleh ahli materi, ahli media sedikit banyak telah memberikan banyak perubahan pada media blog ini. Produk blog sejarah dalam tahap kedua ini sudah terbilang sudah baik meskipun masih terdapat saran dan kritik dari ahlia materi maupun ahli media, diantarnya dari ahli materi yaitu tentang kekurangan dan kelebihan terori masuknya HinduBuddha, sedangkan meurut ahli media dibutuhkan memberikan saran untuk diberi beberap fitur tambahan diantarnya adalah video call, chat on, video, fitur tambahan.

Produk akhir pada penelitian pengembangan (research and development) ini adalah media pembelajaran sejarah dengan blog sejarah yang dapat digunakan untuk mendukung pembelajaran sejarah siswa kelas XI. Media dengan blog sejarah merupakan media pembelajaran yang didesain untuk mendukung pembelajaran sejarah tetapi dapat juga digunakan secara mandiri, baik didampingi guru ataupun tidak didampingi. Pengembangan media pembelajaran dengan blog sejarah ini, dilakukan melalui beberapa tahap yaitu (1) potensi masalah, (2) pengumpulan informasi / data (3) design produk, (4) validasi design, (5) perbaikan design, (6) Uji coba produk, (7) Revisi produk, (8) ujicoba pemakaian, (9) revisi produk (10) pembuatan produk. Dari tahap tersebut diperoleh pengembangan media pembelajaran dengan blog sejarah, yang meliputi pengembangan materi dan pengembangan media pembelajaran. Hasil dari pengembangan materi berupa bahan materi masuknya Hindu Buddha di Indonesia.
Validasi yang dilakukan oleh ahli atau pakar bertujuan untuk meminta pengesahan dan persetujuan kelayakan media yang telah dibuat. Berdasarkan uji ahli materi dan ahli media pembelajaran, menyatakan bahwa media yang dihasilkan layak digunakan sebagai media pembelajaran. Akan tetapi perlu adanya beberapa perbaikan. Setelah media direvisi maka selanjutnya media di uji pemakai terbatas untuk yakni siswa kelas XI IPA SMA 2 Ngaglik, Sleman. Uji coba produk dilakukan dengan memeberikan lembar penilaian untuk diisi oleh seluruh siswa kelas XI IPA SMA 2 Ngaglik, Sleman.

Penilaian kelayakan media oleh uji ahli dan uji pemakai terbatas untuk siswa pada penelitian ini menggunakan angket sebagai instrumen penilaiannya. Skala yang digunakan dalam penilaian tersebut menggunakan skala yang terdapat pada buku nya Prof. Suharsimi Arikunto (1993: 207), yaitu dengan skor penilaian 1 sampai 4. Skor 1 berarti kurang baik, skor 2 berarti cukup, skor 3 berarti baik dan skor 4 berarti sangat baik. Selanjutnya data yang terkumpul diproses dengan cara dijumlahkan dan kemudian dibandingkan dengan jumlah yang diharapkan dan diperoleh persentase. Kriteria penilaian media pembelajaran yaitu 0-39\% berarti kurang baik, 40-55\% berarti cukup, $56-75 \%$ baik dan $76-100 \%$ berarti sangat baik.

Berdasarkan penilaian para ahli dan uji coba produk maka dihasilkan data sebagai berikut:

Berdasarkan Ahli Materi

- Aspek pembelajaran memperoleh $75 \%$ dengan kategori sangat baik.

- Aspek materi memperoleh $84 \%$ dengan kategori sangat baik.

Secara keseluruhan penilaian ahli materi adalah sebesar $81,3 \%$ dengan kategori

M. Nur Rokhman, dkk, Pengembangan Media Blog Sejarah untuk Pembelajaran Sejarah di SMA 


\section{Volume 10 No 2 Maret 2015}

sangat baik sebagai media pembelajaran sejarah dengan blog sejarah pada materi masuknya hindu Buddha di Indonesia.

Berdasarkan Ahli Media Pembelajaran

- Aspek komunikasi memperoleh 83,3\% dengan kategori sangat baik.

- Aspek desain memperoleh 78,1\% dengan kategori baik.

- Aspek format sajian memperoleh $87,5 \%$ dengan kategori sangat baik.

Secara keseluruhan penilaian ahli media adalah sebesar 80,8\% dengan kategori sangat baik sebagai media pembelajaran sejarah dengan blog sejarah pada materi masuknya Hindu Buddha di Indonesia.

Berdasarkan Evaluasi Guru Pengampu

- Aspek materi memperoleh 80,5\% dengan kategori baik.

- Aspek media memperoleh $86,7 \%$ dengan kategori sangat baik.

Secara keseluruhan penilaian guru pengampu adalah sebesar 84,4\% dengan kategori sangat baik sebagai media pembelajaran sejarah dengan blog sejarahpada materi masuknya Hindu Buddha di Indonesia.

\section{Berdasarkan Uji Coba Produk}

- Aspek materi memperoleh 82,2\% dengan kategori sangat baik.

- Aspek strategi pembelajaran memperoleh 80,6\% dengan kategori sangat baik.

- Aspek kualitas teknik memperoleh 79,7\% dengan kategori sangat baik.

Secara keseluruhan penilaian pada uji coba produk adalah sebesar $82,9 \%$ dengan kategori sangat baik sebagai media pembelajaran sejarah dengan blog sejarah pada materi masuknya Hindu Buddha di Indonesia.

\section{Penutup}

Secara garis besar hasil penelitian pengembangan media blog sejarah dapat disampaikan bahwa hasil pembuatan media pembelajaran dengan blog sejarah adalah berupa pengembangan materi dan pengembangan media. Hasil dari pengembangan materi berupa bahan materi Masuknya Hindu buddha di Indonesia. Hasil dari pengembangan media adalah berupa media pembelajaran sejarah berbantuan komputer dan internet pada materi masuknya Hindu buddha di Indonesia.

Hasil uji kelayakan terhadap media pembelajaran sejarah dengan blog sejarah yang dikembangkan, menurut ahli materi memperoleh persentase sebesar 81,3\%. Hasil tersebut termasuk dalam kategori sangat baik. Penilaian menurut ahli media pembelajaran, memperoleh persentase $80,8 \%$. Hasil tersebut termasuk dalam kategori sangat baik. Evaluasi guru pengampu memperoleh 84,4\%. Hasil tersebut termasuk dalam kategori sangat baik. Penilaian menurut siswa pada uji coba produk, memperoleh persentase $82,9 \%$. Penilaian tersebut termasuk dalam kategori sangat baik. Jumlah rerata adalah $82,2 \%$ dengan kategori sangat baik. Dengan demikian berdasarkan rerata hasil uji ahli materi, uji ahli media pembelajaran, evaluasi guru pengampu dan uji coba produk, media pembelajaran dengan blog sejarah dinyatakan layak digunakan sebagai media pendukung pembelajaran sejarah pada materi masuknya Hindu di Indonesia.

\section{Ucapan Terima Kasih}

Dalam kesempatan ini, penulis mengucapkan terima kasih kepada berbagai pihak yang telah membantu terlaksananya penelitian ini. Tak lupa, penulis juga menyampaikan ucapan terima kasih kepada 
dewan redaksi Jurnal Istoria terbitan Pendidikan Sejarah, Fakultas Ilmu Sosial, Universitas Negeri Yogyakarta atas kesempatan yang diberikan sehingga tulisan ini dapat dipublikasikan pada edisi Maret 2015.

\section{Daftar Pustaka}

Andi Prastowo. (2011). Panduan Kreatif membuat Bahan Ajar Inovatif. Yogyakarta : Diva Press.

Arsyad, Azhar. (2003). Media Pembelajaran. Jakarta : Rajawali Pers

Mulyasa, E., (2006). Implementasi Kurikulum Tingkat Satuan pendidikan Kemandirian Guru dan Kepala Sekolah. Jakarta : Bumi Aksara.

Hasnul Arifin. (2010). 1 Menit membuat web \& blog. Yogyakarta : Mediakom.

Kuntowijoyo. (1995). Pengantar Ilmu Sejarah. Yogyakarta: Yayasan Bentang Budaya.

Nana Syaodih. (2009). Metode Penelitian Pendidikan. Bandung: Remaja Rosdakarya

Oemar Hamalik. (2008). Proses Belajar Mengajar. Jakarta: Bumi Aksara.

Ridwan Sanjaya \& Fredy Setyawan. (2010). $101+$ Solusi Ahli Komputer : Internet, Website dan Blog .Jakarta : elek media

Sadiman, A.S., Rahardjo, R., Haryono, A., \& Rahadjito. (2002). Media
Pendidikan: Pengertian,

Pengembangan dan

Pemanfaatannya, edisi 1. Jakarta: Penerbit Rajawali.

Sardiman. (2007). Sejarah SMA Kelas X. Jakarta : Yudhistira

Sidi Gazalba. (1966). Pengantar Sejarah Sebagai Ilmu untuk Meningkatkan Tingkat Pengetahuan Menengah dan Perguruan Tinggi. Jakarta: Bhratara.

Soekmono. (1981). Sejarah Kebudayaan Indonesia 3. Yogyakarta : Kanisius

Soewarso. (2000). Cara Penyampaian Pendidikan Sejarah Untuk Membangkitkan Minat Peserta Didik Mempelajari Bangsanya. DEPDIKNAS.

Sudjana, N. \& Rivai, A. (1992). Media Pengajaran. Bandung: Penerbit CV. Sinar Baru Badung.

Sugihartono, dkk. (2007). Psikologi Pendidikan. Yogyakarta: UNY Press.

Sugiyono. (2011). Metode Penelitian Kuantitatif dan Kualitatif dan $R \& D$. Bandung : Alfabeta.

Suharsimi Arikunto. (1993). Prosedur Penelitian Suatu Pendekatan Praktik. rev.ed. Jakarta: Rineka Cipta.

Suryanegara, Ahmad Mansur. (2010). Api Sejarah. Bandung : Salamadani

I Gde, Widja. (1989). Dasar-Dasar Pengembangan Strategi serta Metode

M. Nur Rokhman, dkk, Pengembangan Media Blog Sejarah untuk Pembelajaran Sejarah di SMA 
Pengajaran Sejarah. Jakarta: Depdiknas.

Ena, Auda Teda. (2001). Membuat Media Pembelajaran Interaktif dengan Piranti

Wina Sanjaya. (2009). Perencanaan dan LunakPresentasi.www.ialf.edu/kibbi Desain Sistem Pembelajaran. Jakarta: Kencana Prenada Media Group. pa/papers/oudatedaena.docDownload Tgl 12 Juni 2012.

Zaenal Arifin. (2009). Evaluasi Pembelajaran. Bandung: Remaja Rosdakarya.

M. Nur Rokhman, dkk, Pengembangan Media Blog Sejarah untuk Pembelajaran Sejarah di SMA 